\title{
Neotropical Deer Ked or Neotropical Deer Louse Fly, Lipoptena mazamae Rondani (Insecta: Diptera: Hippoboscidae) ${ }^{1}$
}

William H. Kern, Jr. ${ }^{2}$

\section{Introduction}

The Neotropical deer ked, Lipoptena mazamae Rondani, is a common ectoparasite of the white-tailed deer (Odocoileus virginianus) in the southeastern United States. The louse flies (Hippoboscidae) are obligate blood-feeding ectoparasites of birds and mammals. Both adult males and females feed on the blood of their host. They are adapted for clinging to and moving through the plumage and pelage of their hosts. Strongly specialized claws help them cling to the hair or feathers of their particular host species. Deer keds have wings when they emerge from their puparium, but lose their wings once they find a host (deer).

\section{Synonomy}

Lipoptena odocoilei is a synonym of Lipoptena mazamae suppressed by Maa (1965).

\section{Distribution}

This fly is an obligate parasite of white-tailed deer and red brocket deer (Mazama americana). It occurs on white-tailed deer throughout Florida and the southeastern United States north at least to Virginia and Oklahoma (Kocan 2003) and south through Panama in Central America and as far south as northeastern Brazil (Neotropical and southern Nearctic regions) (Bequaert 1942). It also occurs on red brocket deer from Mexico to northern Argentina (Bequaert 1942).

\section{Identification}

Neotropical deer keds are brown, dorso-ventrally flattened flies that live in the pelage of deer. It is the only deer ked currently found on white-tailed deer in the southeastern United States. They are often misidentified as ticks by hunters, but can be identified as insects because they have six legs and three body regions (head, thorax and abdomen). The winged flies are rarely seen because they lose their wings soon after finding a host. Females are larger than males

1. This document is EENY-308, one of a series of Featured Creatures from the Entomology and Nematology Department, Florida Cooperative Extension Service, Institute of Food and Agricultural Sciences, University of Florida. Published: September 2003. This document is also available on Featured Creatures Website at http://creatures.ifas.ufl.edu. Please visit the EDIS Website at http://edis.ifas.ufl.edu. Additional information on these organisms, including many color photographs, is available at the Entomology and Nematology Department website at http://entnemdept.ifas.ufl.edu/. 2. William H. Kern, Jr., Department of Entomology and Nematology, Institute of Food and Agricultural Sciences, University of Florida, Ft. Lauderdale, FL.

The Institute of Food and Agricultural Sciences (IFAS) is an Equal Employment Opportunity - Affirmative Action Employer authorized to provide research, educational information and other services only to individuals and institutions that function without regard to race, creed, color, religion, age, disability, sex, sexual orientation, marital status, national origin, political opinions or affiliations. For information on obtaining other extension publications, contact your county Cooperative Extension Service office. Florida Cooperative Extension Service / Institute of Food and Agricultural Sciences / University of Florida / Larry R. Arrington, Interim Dean 
(females 3.5-4.5 $\mathrm{mm}$ and male $3 \mathrm{~mm}$ head and body length). They have a tough exoskeleton that protects them from being crushed by the grooming host and this adds to the perception that these are ticks. They are larger than most lice and move faster than either ticks or lice.

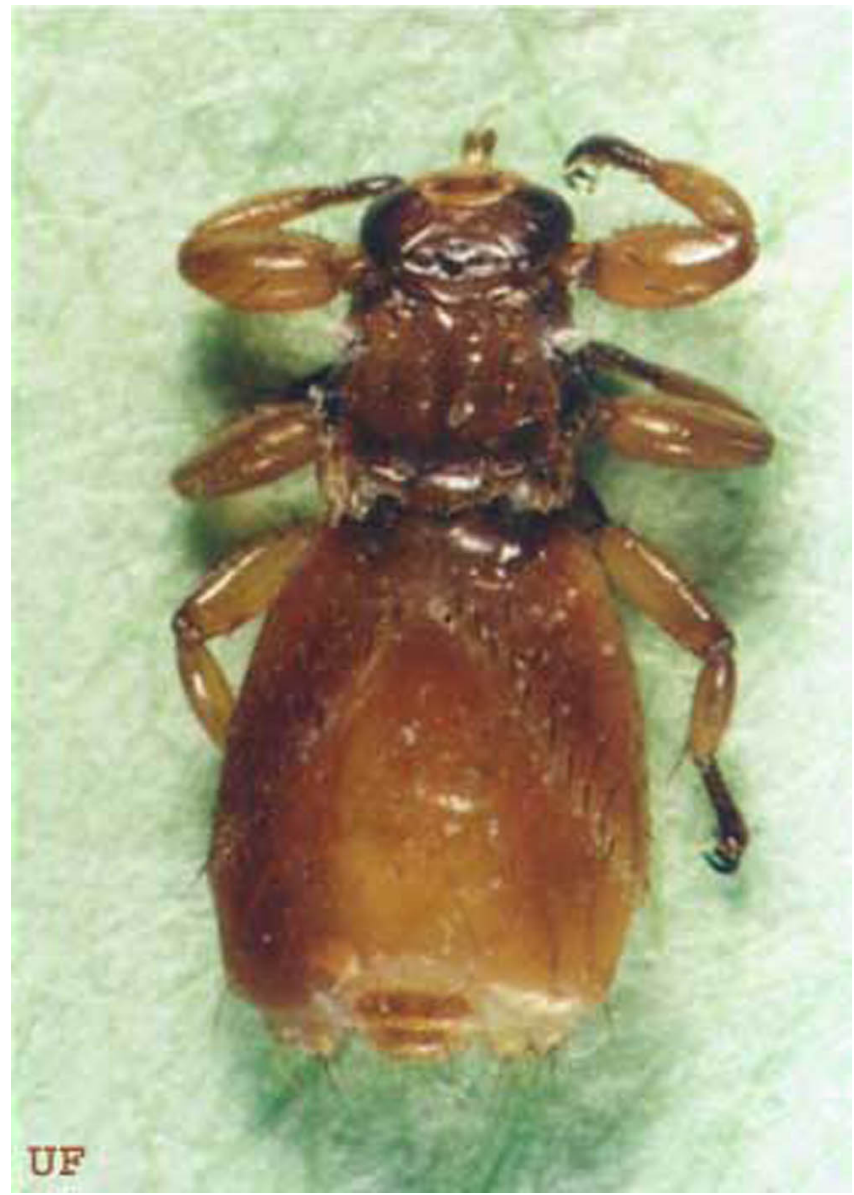

Figure 1. Dorsal view of a female deer ked, Lipoptena mazamae Rondani. Credits: Photograph by: Karen Wheeler, University of Florida

Other member of this genus that occur on deer are: Lipoptena cervi, the Old World deer ked of red deer (Cervus elephus) and other Old World deer which has been introduced into New England. Lipoptena depressa, the western American deer ked, found on mule deer (Odocoileus hemionus) and white-tailed deer in the western United States and Canada along the Rocky Mountains. A related species is Neolipoptena ferrisi, the Pacific deer ked, found on white-tailed and mule deer from British Columbia, Canada to Baja California, Mexico (Maa 1965, Stickland et al 1981).

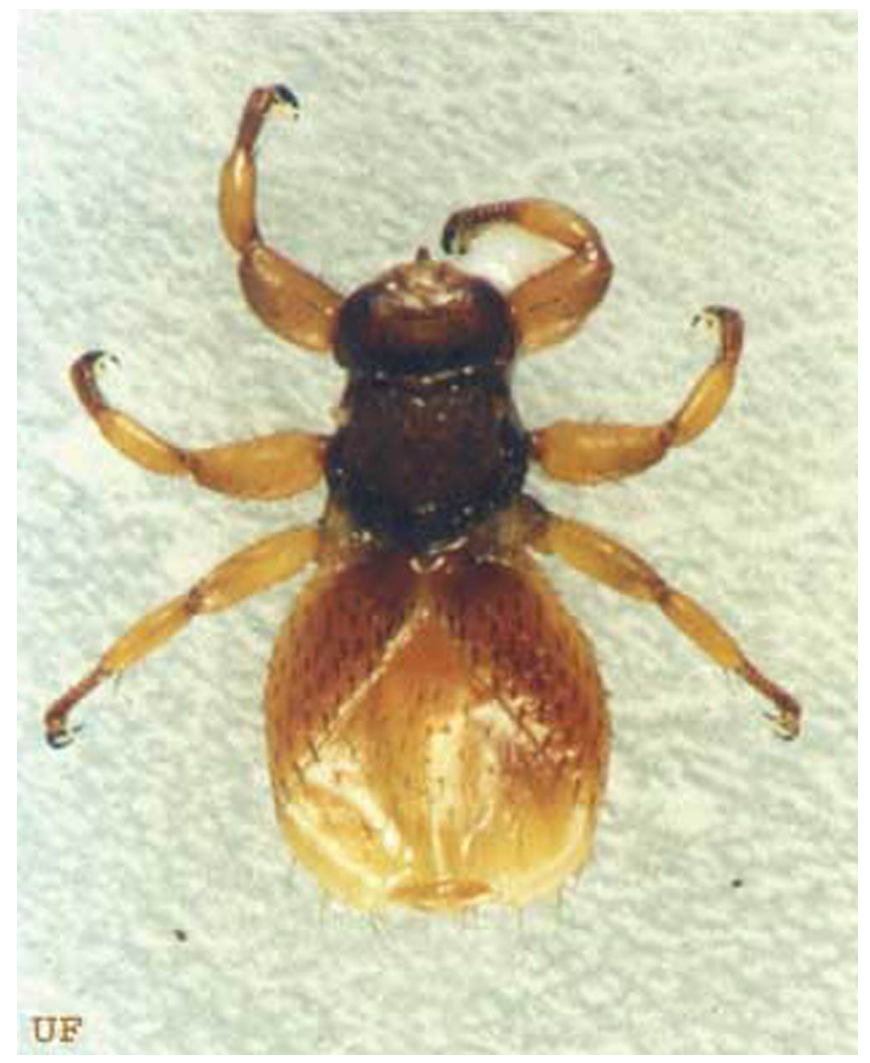

Figure 2. Dorsal view of a male deer ked, Lipoptena mazamae Rondani. Credits: Photograph by: Karen Wheeler, University of Florida

\section{Life Histories and Habitat}

Deer keds have a very interesting reproductive strategy. The female produces one larva at a time and retains the developing larva in her body until it is ready to pupate. The larva feeds on the secretions of a "milk gland" in the uterus of its mother. After three larval instars, the larva has reached its maximum size, the mother gives birth to the white pre-pupa which immediately begins to darken and form the puparium or pupal shell. The pupa falls from the deer and is usually deposited where the deer bedded. When the fly has completed its metamorphosis, the winged adult emerges from the puparium and flies in search of a host. After finding a host the adult fly breaks off its wings and is now permanently associated with that one deer. Both sexes feed on the blood of the host deer.

\section{Hosts}

This fly is an obligate parasite of New World deer. It has been collected on white-tailed deer (Odocoileus virginianus) from the southeastern 


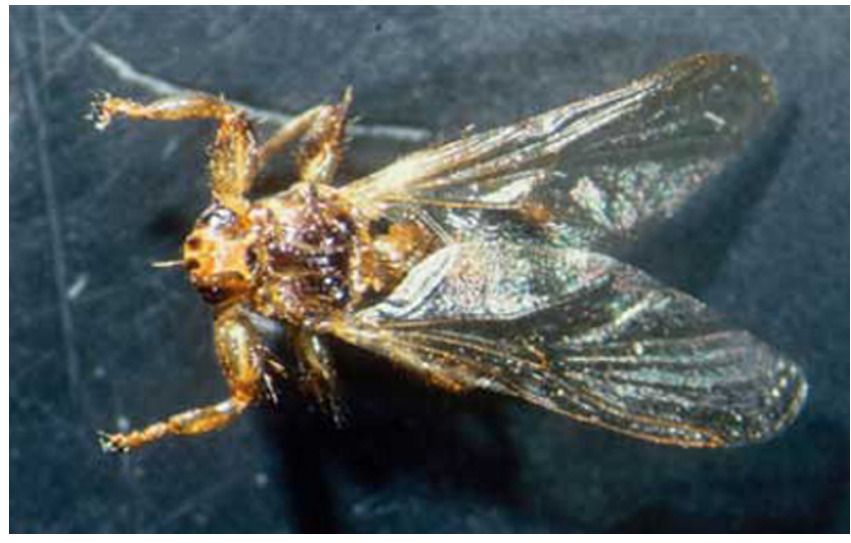

Figure 3. Lipoptena cervi, a species related to Lipoptena mazamae Rondani, showing a young fly prior to losing its wings. Credits: Photograph by: Steve Jacobs, Penn State University

United States to Brazil (Bequaert 1942) and red brocket deer (Mazama americana) from Mexico and Central America (Wenzel and Tipton, 1966) to northern Argentina (Bequaert 1942). In ectoparasite studies conducted by Donald J. Forrester and Sam R. Telford, Jr., they found that $84 \%$ of 237 deer sampled from 1984 to 1989 in Collier County, Florida were infested with Neotropical deer keds and $31 \%$ of 26 deer sampled in 1988 and 1989 in Monroe and Dade counties, Florida were infested (Forrester 1992). Two bucks ( $31 / 2$ and $11 / 2$ years old) were examined in Collier County, FL in October 2001 and both harbored large populations $(>50)$ of wingless adult flies. A doe (1 1/2 years old) was examined in Calhoun County, FL in November 2002 and had over one hundred adult flies in the pelage on its neck, flanks and belly (Kern, personal observation).

\section{Medical and Veterinary Importance}

No parasites, predators, or diseases have been described from the Neotropical deer ked on white tailed deer. They are not known to transmit any disease to deer or humans. Hunters dressing harvested deer are likely to encounter these flies and possibly may be bitten.

\section{Selected References}

Bequaert J. 1942. A monographof the Melophaginae, or ked-flies, of sheep, goats, deer and antelopes (Diptera, Hippoboscidae). Entomologica Americana 22: 65-220.
Davidson WR, Nettles VF. 1997. Field Manual of Wildlife Diseases in the Southeastern United States. Second edition. Southeastern Cooperative Wildlife Disease Study, The University of Georgia, Athens, GA. 417 pp.

Forrester DJ. 1992. Parasites and Diseases of Wild Mammals in Florida. University Press of Florida, Gainesville, FL. 460 pp.

Kocan AA. (January 2003). Parasitic and infectious diseases of white-tailed deer in Oklahoma. http://www.cvm.okstate.edu/instruction/kocan/vpar53 33/deerpar.htm (5 September 2003).

Maa TC. 1965. A synopsis of the Lipopteninae. Journal of Medical Entomology 2: 233-248.

Strickland RK, Gerrish RR, Smith JS. 1981. Chapter 24. Arthropods. In Diseases and Parasites of White-tailed deer. Edited by Davidson WR. et al. Misc. Publication No. 7 of the Tall Timbers Research Station, Tallahassee, FL. P. 376-377.

Theodor O. 1975. Diptera pupipara; Fauna Palaestina-Insecta I. The Israel Academy of Sciences and Humanities, Jerusalem, Israel. 170 pp.

Wenzel RL, Tipton VJ. 1966. Ectoparasites of Panama. Field Museum of Natural History, Chicago, IL. p. 390 